\title{
Efektivitas Pilates Exercise Terhadap Peningkatan Activity of Daily Living (ADL) pada Lanjut Usia \\ ${ }^{1}$ Dhea Anandha Aulia, ${ }^{2}$ Indah Ameilia Radnaningayu, ${ }^{3}$ Eka Anintyas Pandini, ${ }^{4}$ Yasyinta Ayu Qoriah, ${ }^{5}$ Fadiya Yasmin Robbani \\ D-IV Fisioterapi, Poltekkes Kemenkes Jakarta III \\ Jl. Melati 2 No.15, RT 001/RW 009, Jatiwarna, Kec. Pd. Melati, Kota Bks, Jawa Barat, 17415E-mail :
}

dheaanandhaa@gmail.com

\section{ABSTRAK}

Latar Belakang: Fenomena peningkatan populasi lansia menjadi isu penting bagi dunia. Saat ini, semakin banyak masalah penurunan kemampuan fisik lansia yang dapat memengaruhi kemandirian Activity of Daily Living (ADL) pada lansia. Sehingga, diberikan intervensi Pilates Exercise yang dapat menjaga fungsional fisik demi mewujudkan lansia yang lebih mandiri. Tujuan: Untuk mengetahui efektivitas Pilates Exercise terhadap peningkatan Activity of Daily Living (ADL) pada lansia. Metode: Jenis penelitian ini Systematic Literature Review dengan variabel bebas "Pilates Exercise" dan variabel terikat "Activity of Daily Living (ADL)". Sampel penelitian pada lansia sehat dan tidak memiliki masalah kesehatan kronis. Pengumpulan data dilakukan secara online melalui 3 search engine dengan kata kunci yang dikembangkan berdasarkan PICOS. Waktu pengumpulan data tanggal 30 Mei 2021. Hasil: Didapatkan 9 literatur dengan desain Clinical Trial dan Randomized Controlled Trial, menghasilkan adanya peningkatan Activity of Daily Living (ADL) yang diukur dengan Barthel Index, Katz Scale, IADL Scale, Senior Fitness Test (SFT) Battery, dan GDLAM Index. Kesimpulan: Secara keseluruhan, penelitian ini melihat adanya peningkatan Activity of Daily Living (ADL) pada lansia dengan intervensi Pilates Exercise.

Kata kunci: Activity of Daily Living, Lansia, dan Pilates Exercise

\section{ABSTRACT}

Background: The increase of the elderly population phenomenon has become the world important issue. Currently, there are more problems concerning the decrease of the elderly physical abilities in which can affect the achievement of Activity of Daily Living (ADL) in the elderly. Therefore, Pilates Exercise intervention is given to maintain physical function in order to create more active and productive elderly. Objective: To determine the effectiveness of Pilates Exercise towards the elderly Activity of Daily Living $(A D L)$. Method: This research is a study of literature using the independent variable "Pilates Exercise" and the dependent "Activity of Daily Living (ADL)". Research sample is taken from the healthy elderly people without chronic health problems. Data collection is performed online through 3 search engines with developed keywords based on PICOS. Data collection time is May 30, 2021. Results: 9 literatures are found with Clinical Trial design and Randomized Controlled Trial, resulting in an increase in Activity of Daily Living (ADL) as measured by Barthel Index, Katz Scale, IADL Scale, Senior Fitness Test (SFT) Battery, and GDLAM Index. Conclusion: Overall, this study percieves an increase in Activity of Daily Living $(A D L)$ in the elderly with Pilates Exercise intervention.

Keywords: Activity of Daily Living, Elderly, and Pilates Exercise 


\section{Pendahuluan}

Lanjut usia merupakan seseorang yang telah mencapai tahap akhir perkembangan pada daur kehidupan manusia (Uraningsari \& Djalali, 2016). Menurut Peraturan Pemerintah Republik Indonesia Nomor 43 Tahun 2004, lanjut usia adalah seseorang yang telah mencapai usia 60 (enam puluh) tahun ke atas. Masa lanjut usia dibagi menjadi empat, yaitu usia pertengahan (middle age) 45-59 tahun, usia lanjut (elderly) 60-74 tahun, usia lanjut tua (old) 75-90 tahun, dan usia sangat tua (very old) diatas 90 tahun (WHO, 2015).

Pada tahun 2019, populasi lansia secara global semakin meningkat, yakni orang yang berusia 60 tahun ke atas telah mencapai 9\%. Populasi lansia diperkirakan akan bertambah dua kali lipat pada tahun 2050, sekitar 1,5 miliar (United Nations, 2019). Indonesia juga mengalami penuaan penduduk karena jumlah lansia di Indonesia pada tahun 2019 meningkat menjadi 10,3\%, di tahun 2025 diperkirakan akan mencapai $11,1 \%$, dan akan mencapai $12,9 \%$ pada tahun 2030 (BKKBN, 2019).

Menurut Riskesdas (2018), semakin tua umur lansia, semakin kecil persentase lansia yang dapat beraktivitas secara mandiri. Hal tersebut dapat memengaruhi tingkat ketergantungan lansia di Indonesia, di antaranya yaitu $74,25 \%$ lansia mandiri, 22,01\% ketergantungan ringan, $1,15 \%$ ketergantungan sedang, $1,02 \%$ ketergantungan berat, $1,58 \%$ ketergantungan total. Hal ini disebabkan karena semakin bertambahnya usia, seseorang akan mengalami penuaan (aging). Selama proses penuaan, perubahan fisik, fisiologis, psikologis, dan sosial dapat memengaruhi kemampuan untuk mandiri dalam menjalani aktivitas seharihari. Menurunnya kemandirian pada lanjut usia dapat menyebabkan ketergantungan pada orang lain, menurunkan kualitas hidup, dan mengganggu kesehatan. Sehingga, sangat penting untuk menjaga kemampuan dan kemandirian lansia dalam Activity of Daily Living (ADL) (Andrew \& Wong, 2012).

Sebuah tinjauan inisiatif promosi dan preventif kesehatan menunjukkan bahwa metode dengan berbagai tingkat efektivitas dianalisis untuk meningkatkan mobilitas, kekuatan otot, keseimbangan, dan Activity of Daily Living (ADL) melalui studi dan cara ukur yang berbeda. Namun, seiring dengan perkembangan teknologi yang semakin pesat, metode latihan yang dapat meningkatkan kemandirian pada lansia semakin bertambah. Penelitian Gabizon et al., (2016), menunjukkan bahwa terdapat latihan berbasis fisioterapi yang aman dan tidak terlalu berisiko bagi lansia, yaitu Pilates Exercise yang merupakan salah satu jenis terapi latihan.

Pilates Exercise adalah metode latihan yang berfokus pada kontrol gerakan, posisi tubuh, dan pernapasan. Pilates terbukti efektif untuk meningkatkan fleksibilitas, kepadatan tulang, keseimbangan dinamis, perubahan indeks massa 
D.A Aulia, I.A Radnaningayu, E.A Pandini, Y.A Qoriah \& F.Y Robbani Fisiomu.2021 Vol 2(3): 220-233 DOI: $10.23917 /$ fisiomu.v2i3.15006

tubuh, kekuatan, serta daya tahan otot yang bermanfaat untuk meningkatkan kemandirian lansia dalam melakukan aktivitas sehari-hari (Fourie et al., 2013). Pada penelitian Mueller et al., (2020), dilakukan dua jenis program intervensi, yaitu Mat Pilates Exercise dan Apparatus Pilates Exercise pada lansia sehat dengan hasil adanya peningkatan functional capacity dan functional autonomy yang menjadi tolak ukur terhadap kemandirian lansia. Oleh karena itu, tinjauan sistematis ini dilakukan untuk mengidentifikasi jenis dan karakteristik Pilates Exercise terhadap peningkatan Activity of Daily Living (ADL) pada lanjut usia.

\section{Metode Penelitian}

Penelitian ini menggunakan jenis penelitian deskriptif dengan desain studi Systematic Literature Review dan hasil penelitian menggunakan literatur sebagai sumber data. Metode pengumpulan data dilakukan dengan mengunduh literatur pada 3 search engine, yaitu Elsevier: Journal of Bodywork and Movement Therapies, Semantic Scholar, dan Europe PMC.

Waktu pencarian dan pengolahan data literatur dilakukan pada tanggal 12 April-30 Mei 2021. Populasi yang diambil pada penelitian ini adalah semua literatur yang relevan dengan perlakuan, yaitu Pilates Exercise dan outcome Activity of Daily Living (ADL) pada lansia sehat. Peneliti melakukan pencarian literatur berdasarkan pendekatan PICOS, yaitu P
(Person) yaitu Elderly, I (Intervention) yaitu Pilates Exercise, C (Comparison) tidak ditentukan, kemudian $\mathrm{O}$ (Outcome) yaitu Activity of Daily Living, dan S (Studies) yaitu Clinical Trial/Eksperimental atau Randomized Controlled Trial (RCT).

Hasil yang didapat berdasarkan kata kunci kemudian diseleksi berdasarkan kriteria inklusi dan eksklusi. Kriteria inklusi penelitian ini meliputi lansia sehat yang diberikan intervensi Pilates Exercise dengan outcome Activity of Daily Living (ADL); desain penelitian Clinical Trial atau Randomized Controlled Trial (RCT); dan tahun publikasi antara 2016-2021. Kriteria eksklusi penelitian ini adalah literatur yang tidak berbahasa Inggris dan Indonesia. Kemudian, dilakukan pengecekan duplikasi literatur dengan menggunakan aplikasi Mendeley. Selanjutnya, dilakukan pengolahan data meliputi tahun terbit, desain penelitian, subjek/sampel, perlakuan pada kelompok intervensi dan kelompok pembanding (jika ada), outcome dan cara ukurnya, serta analisis univariat dan bivariat dengan hasilnya.

\section{Hasil}

Proses pencarian yang dilakukan pada 3 search engine dapat dilihat pada diagram PRISMA berikut ini. 
D.A Aulia, I.A Radnaningayu, E.A Pandini, Y.A Qoriah \& F.Y Robbani

Fisiomu.2021 Vol 2(3): 220-233

DOI: $10.23917 /$ fisiomu.v2i3.15006

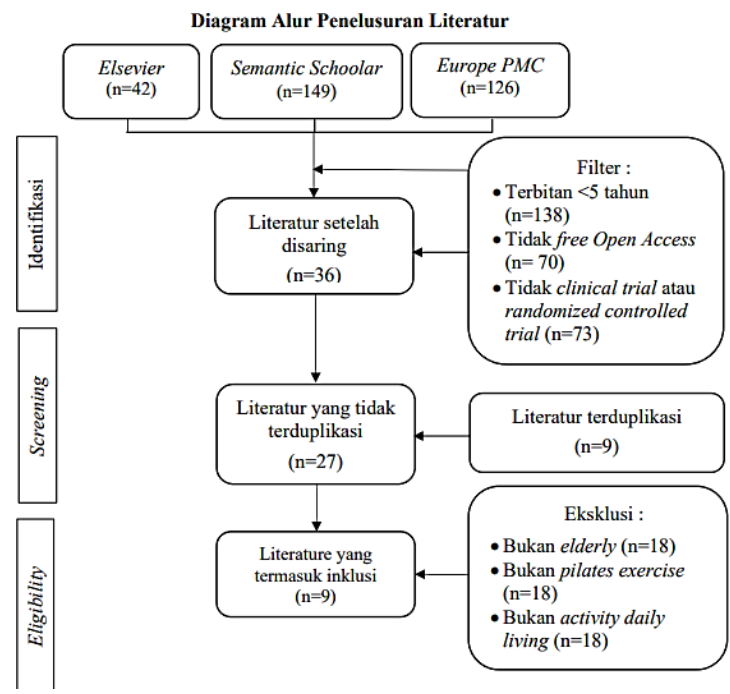

Pada hasil awal pencarian literatur dengan kata kunci di 3 search engine yang berbeda, didapatkan sejumlah 317 literatur dengan hasil akhir didapatkan 27 literatur lalu diunduh dan dilakukan pemeriksaan duplikasi sebanyak 9 literatur terduplikasi. Setelah itu, literatur dilakukan ekstraksi data kemudian data dikoding untuk dimasukkan ke dalam perangkat lunak pengolahan data. Hasil dari pengolahan data terdapat pada tabel 1 di bawah ini.

Gambar 1. Diagram Alur Proses Pencarian Literatur

Tabel 1. Distribusi Studi Berdasarkan Karakteristik Studi

\begin{tabular}{|c|c|c|c|}
\hline No & Uraian & Jumlah & Persentase \\
\hline \multirow[t]{2}{*}{1} & Outcome & & \\
\hline & Activity of Daily Living (ADL) & 9 & $100 \%$ \\
\hline \multirow[t]{5}{*}{2} & Alat Ukur & & \\
\hline & - GDLAM Index & 4 & $44,4 \%$ \\
\hline & - Senior Fitness Test (SFT) Battery & 3 & $33,3 \%$ \\
\hline & - Barthel Index dan IADL Scale & 1 & $11,1 \%$ \\
\hline & - Senior Fitness Test (SFT) Battery, IADL Scale, dan Katz Scale & 1 & $11,1 \%$ \\
\hline \multirow[t]{3}{*}{3} & Desain Studi & & \\
\hline & - Clinical Trial & 5 & $55,5 \%$ \\
\hline & - Randomized Controlled Trial & 4 & $44,4 \%$ \\
\hline 4 & Intervensi Pilates Exercise & 9 & $100 \%$ \\
\hline \multirow[t]{11}{*}{5} & Pembanding & & \\
\hline & Control Group & & \\
\hline & - Tidak ada Control Group & 4 & $44,4 \%$ \\
\hline & - Tanpa perlakuan & 3 & $33,3 \%$ \\
\hline & - Physical Exercise & 1 & $11,1 \%$ \\
\hline & - Static Stretching Exercise & 1 & $11,1 \%$ \\
\hline & Grup Pembanding & & \\
\hline & - Tidak ada Grup pembanding & 6 & $66,6 \%$ \\
\hline & - Tai Chi Chuan & 1 & $11,1 \%$ \\
\hline & - Muscular Exercise & 1 & $11,1 \%$ \\
\hline & - Functional Gymnastics dan Resistance Training & 1 & $11,1 \%$ \\
\hline
\end{tabular}


D.A Aulia, I.A Radnaningayu, E.A Pandini, Y.A Qoriah \& F.Y Robbani Fisiomu.2021 Vol 2(3): 220-233

DOI: $10.23917 /$ fisiomu.v2i3.15006

\begin{tabular}{|c|c|c|c|}
\hline \multirow[t]{4}{*}{6} & Besar Sampel & & \\
\hline & - $\mathrm{N}=16-60$ & 6 & $66,6 \%$ \\
\hline & - $\mathrm{N}=61-105$ & 2 & $22,2 \%$ \\
\hline & - $\mathrm{N}=106-150$ & 1 & $11,1 \%$ \\
\hline \multirow[t]{3}{*}{7} & Usia Sampel & & \\
\hline & - Tidak dijelaskan & 0 & $0,00 \%$ \\
\hline & - > 60 tahun & 9 & $100 \%$ \\
\hline \multirow[t]{15}{*}{8} & Dosis & & \\
\hline & Durasi & & \\
\hline & - 45 menit & 1 & $11,1 \%$ \\
\hline & - 50 menit & 3 & $33,3 \%$ \\
\hline & - 60 menit & 5 & $55,5 \%$ \\
\hline & Frekuensi & & \\
\hline & - $2 \mathrm{kali} / \mathrm{minggu}$ & 7 & $77,7 \%$ \\
\hline & - $3 \mathrm{kali} / \mathrm{minggu}$ & 2 & $22,2 \%$ \\
\hline & Lama Intervensi & & \\
\hline & - 6 minggu & 1 & $11,1 \%$ \\
\hline & - 8 minggu & 2 & $22,2 \%$ \\
\hline & - 10 minggu & 1 & $11,1 \%$ \\
\hline & - 16 minggu & 3 & $33,3 \%$ \\
\hline & - 18 minggu & 1 & $11,1 \%$ \\
\hline & - 20 minggu & 1 & $11,1 \%$ \\
\hline \multirow[t]{3}{*}{9} & Output & & \\
\hline & - ANOVA & 8 & $88,8 \%$ \\
\hline & - ANCOVA & 1 & $11,1 \%$ \\
\hline
\end{tabular}

Tabel 2. Karakteristik dan Detail Literatur

\begin{tabular}{|c|c|c|c|c|}
\hline Penulis & Participants & Cara Ukur & Perlakuan & Hasil \\
\hline $\begin{array}{l}\text { (Mueller } \\
\text { et al., } \\
2020)\end{array}$ & $\begin{array}{l}\mathrm{N}=48 \\
\text { Usia 60-69 } \\
\text { tahun, } \\
\text { Lansia } \\
\text { Sehat }\end{array}$ & $\begin{array}{l}\text { - Katz Scale } \\
\text { - IADL } \\
\text { Scale } \\
\text { - Senior } \\
\text { Fitness } \\
\text { Test (SFT) } \\
\text { Battery }\end{array}$ & $\begin{array}{l}\text { - Group } 1(\mathrm{~N}=15) \text { : } \text { Mat Pilates Exercise } \\
\text { - Group } 2(\mathrm{~N}=16) \text { : Apparatus Pilates } \\
\text { Exercise. } \\
\text { - Group } 3(\mathrm{~N}=17) \text { : } \text { Control Group } \\
\text { dengan Physical Exercise. } \\
\text { Masing-masing intervensi dilakukan } \\
\text { sebanyak } 2 \text { kali/minggu dengan setiap } \\
\text { sesi } 50 \text { menit selama } 8 \text { minggu (16 } \\
\text { pertemuan). }\end{array}$ & $\begin{array}{l}\text { Terdapat hasil signifikan dilihat } \\
\text { dari peningkatan nilai mean pada } \\
\text { ketiga grup, yaitu: } \\
\text { 1) Mat Pilates Exercise } \\
\text { - Pre } 87,75 \\
\text { - Post } 107,73 \\
\text { 2) Apparatus Pilates Exercise } \\
\text { - Pre } 87,61 \\
\text { - Post } 101,51 \\
\text { 3) Control Group } \\
\text { - Pre } 80,6 \\
\text { - Post } 86,8 \\
\text { Mat Pilates Exercise Group dan } \\
\text { Apparatus Pilates Exercise Group } \\
\text { memiliki nilai signifikan }(\mathrm{p}<0,05) \text {. }\end{array}$ \\
\hline
\end{tabular}


D.A Aulia, I.A Radnaningayu, E.A Pandini, Y.A Qoriah \& F.Y Robbani

Fisiomu.2021 Vol 2(3): 220-233

DOI: $10.23917 /$ fisiomu.v2i3.15006

\begin{tabular}{|c|c|c|c|c|}
\hline Penulis & Participants & Cara Ukur & Perlakuan & Hasil \\
\hline $\begin{array}{l}\text { (Araújo- } \\
\text { Gomes et } \\
\text { al., 2019) }\end{array}$ & $\begin{array}{l}\mathrm{N}=28 \\
\text { Usia }>60 \\
\text { tahun, } \\
\text { Lansia } \\
\text { Sehat }\end{array}$ & $\begin{array}{l}\text { GDLAM } \\
\text { Index }\end{array}$ & $\begin{array}{l}\text { - Group } 1(\mathrm{~N}=12) \text { : Mat Pilates } \\
\text { - Group } 2(\mathrm{~N}=16) \text { : Tai Chi Chuan } \\
\text { Masing-masing intervensi dilakukan } \\
\text { sebanyak } 2 \text { kali/minggu dengan tiap } \\
\text { sesi } 45 \text { menit selama } 4 \text { bulan ( } 32 \\
\text { pertemuan). }\end{array}$ & 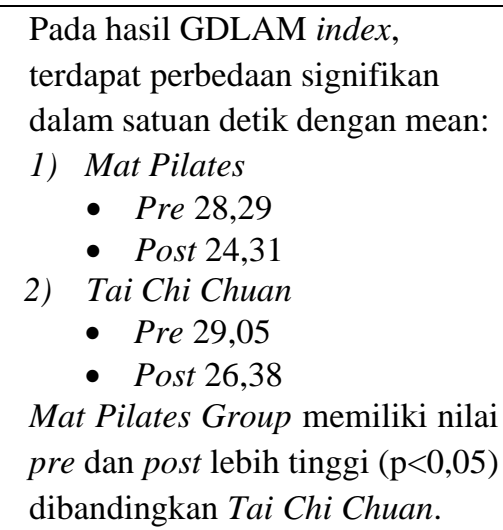 \\
\hline $\begin{array}{l}\text { (Carrasco } \\
\text { et al., } \\
2018)\end{array}$ & $\begin{array}{l}\mathrm{N}=60 \\
\text { Usia } 60-80 \\
\text { tahun, } \\
\text { Lansia } \\
\text { Sehat }\end{array}$ & $\begin{array}{l}\text { GDLAM } \\
\text { Index }\end{array}$ & $\begin{array}{l}\text { - Group } 1(\mathrm{~N}=20) \text { : Pilates Exercise. } \\
\text { - Group } 2(\mathrm{~N}=20) \text { : } \text { Muscular Exercise. } \\
\text { - Group } 3(\mathrm{~N}=17) \text { : Control Group tanpa } \\
\text { perlakuan. } \\
\text { Masing-masing intervensi dilakukan } \\
\text { sebanyak } 2 \text { kali/minggu dengan tiap } \\
\text { sesi } 60 \text { menit selama } 4 \text { bulan } 2 \text { minggu } \\
\text { (36 pertemuan). }\end{array}$ & $\begin{array}{l}\text { Pada hasil GDLAM } \text { index, } \\
\text { terdapat perbedaan signifikan } \\
\text { dalam satuan detik dengan mean: } \\
\text { 1) Pilates Exercise } \\
\text { • Pre } 32,5 \\
\text { - Post } 28,1 \\
\text { 2) Muscular Exercise } \\
\text { - Pre } 36,5 \\
\text { - Post } 31,9 \\
\text { 3) Control Group } \\
\text { - Pre } 36,2 \\
\text { • Post } 33,9 \\
\text { Pilates Exercise } \\
\text { menunjukkan hroup } \\
\text { signifikan (p<0,001) dibandingkan } \\
\text { dengan Muscular Exercise Group } \\
\text { dan Control Group. }\end{array}$ \\
\hline $\begin{array}{l}\text { (Curi et } \\
\text { al., 2017) }\end{array}$ & $\begin{array}{l}\mathrm{N}=61 \\
\text { Usia }>60 \\
\text { tahun, } \\
\text { Lansia } \\
\text { Sehat }\end{array}$ & $\begin{array}{l}\text { Senior } \\
\text { Fitness } \\
\text { Test (SFT) } \\
\text { Battery }\end{array}$ & $\begin{array}{l}\text { - Group } 1(\mathrm{~N}=31) \text { : Pilates Exercise. } \\
\text { - Group } 2(\mathrm{~N}=30) \text { : Control Group tanpa } \\
\text { perlakuan. } \\
\text { Masing-masing intervensi dilakukan } \\
\text { sebanyak } 2 \text { kali/minggu dengan setiap } \\
\text { sesi } 60 \text { menit selama } 4 \text { bulan ( } 32 \\
\text { pertemuan). }\end{array}$ & $\begin{array}{l}\text { Terdapat hasil signifikan dilihat } \\
\text { dari peningkatan dengan mean: } \\
\text { 1) Pilates Exercise } \\
\text { - Pre } 25,71 \\
\text { - Post } 27,87 \\
\text { 2) Control Group } \\
\text { - Pre } 26,03 \\
\text { - Post } 26,13 \\
\text { Pilates Exercise Group lebih } \\
\text { signifikan dibandingkan } \\
\text { Control Group }(\mathrm{p}<0,001) \text {. }\end{array}$ \\
\hline $\begin{array}{l}\text { (Duarte } e t \\
\text { al., 2017) }\end{array}$ & $\begin{array}{l}\mathrm{N}=24 \\
\text { Usia }>60 \\
\text { tahun, } \\
\text { Lansia } \\
\text { Sehat }\end{array}$ & $\begin{array}{l}\text { GDLAM } \\
\text { Index }\end{array}$ & $\begin{array}{l}\text { - Group } 1(\mathrm{~N}=24) \text { : Pilates Exercise } \\
\text { Intervensi dilakukan sebanyak } 2 \\
\text { kali/minggu selama } 60 \text { menit dengan } 2 \\
\text { periode kelas selama } 5 \text { minggu ( } 20 \\
\text { pertemuan). }\end{array}$ & $\begin{array}{l}\text { Pada hasil GDLAM index, } \\
\text { terdapat perbedaan signifikan } \\
\text { dalam satuan detik pada Pilates } \\
\text { Exercise Group dengan mean pre } \\
27,88 \text { dan post } 27,31 \text { serta } \\
\text { (p<0,001). }\end{array}$ \\
\hline
\end{tabular}


D.A Aulia, I.A Radnaningayu, E.A Pandini, Y.A Qoriah \& F.Y Robbani

Fisiomu.2021 Vol 2(3): 220-233

DOI: $10.23917 /$ fisiomu.v2i3.15006

\begin{tabular}{lllll}
\hline Penulis & Participants & Cara Ukur & \multicolumn{1}{c}{ Perlakuan } & \multicolumn{1}{c}{ Hasil } \\
\hline (Bertoli & $\mathrm{N}=18$ & Senior & - Group 1 (N=10): Mat Pilates Exercise. & Terdapat peningkatan pada Mat \\
et al., & Usia $>60$ & Fitness & Intervensi dilakukan sebanyak 3 & Pilates Group dengan nilai mean \\
$2017)$ & tahun, & Test $(\mathrm{SFT})$ & kali/minggu dengan setiap sesi 50 & pre 5,95 dan post 7 serta (p<0,05). \\
& Lansia & Battery & menit selama 6 minggu (18 pertemuan). & \\
& Sehat & & & \\
\hline
\end{tabular}



Pilates Exercise Group lebih signifikan dibandingkan Control Group dengan nilai $(\mathrm{p}<0,05)$.

\begin{tabular}{|c|c|c|c|c|}
\hline $\begin{array}{l}\text { (Vasconc } \\
\text { elos et } \\
\text { al., 2016) }\end{array}$ & $\begin{array}{l}\mathrm{N}=148 \\
\text { Usia }>60 \\
\text { tahun, } \\
\text { Lansia } \\
\text { Sehat }\end{array}$ & $\begin{array}{l}\text { Senior } \\
\text { Fitness } \\
\text { Test (SFT) } \\
\text { Battery }\end{array}$ & $\begin{array}{l}\text { - Group } 1(\mathrm{~N}=37) \text { : Pilates Exercise } \\
\text { dengan Hydrogymnastics. } \\
\text { - Group } 2(\mathrm{~N}=73) \text { : Functional } \\
\text { Gymnastics. } \\
\text { - Group } 3(\mathrm{~N}=37) \text { : Resistance Training. } \\
\text { Intervensi dilakukan sebanyak } 2 \\
\text { kali/minggu dengan setiap sesi } 60 \\
\text { menit selama } 4 \text { bulan (32 pertemuan). }\end{array}$ & $\begin{array}{l}\text { Pada hasil Senior Fitness Test } \\
\text { (SFT) Battery, terdapat perbedaan } \\
\text { signifikan dalam satuan detik pada } \\
\text { nilai mean: } \\
\text { 1) Pilates Exercise } \\
\text { - Pre } 9,4 \\
\text { - Post } 10,82 \\
\text { 2) Functional Gymnastics } \\
\text { - Pre 9,5 } \\
\text { - Post } 10,81 \\
\text { 3) Control Group } \\
\text { - Pre 10,01 } \\
\text { - Post 10,06 } \\
\text { Pilates Exercise } \quad \text { Group } \\
\text { menunjukkan hasil yang } \\
\text { signifikan (p<0,05) dibandingkan } \\
\text { dengan Functional Gymnastics } \\
\text { Group dan Control Group. }\end{array}$ \\
\hline $\begin{array}{l}\text { (Gabizon } \\
\text { et al., } \\
2016)\end{array}$ & $\begin{array}{l}\mathrm{N}=88 \\
\text { Usia }>65 \\
\text { tahun, } \\
\text { Lansia } \\
\text { Sehat }\end{array}$ & $\begin{array}{l}\text { - Barthel } \\
\text { Index } \\
\text { - IADL } \\
\text { Scale }\end{array}$ & $\begin{array}{l}\text { - Group } 1(\mathrm{~N}=44) \text { : Pilates Exercise. } \\
\text { - Group } 2(\mathrm{~N}=44) \text { : } \text { Control Group tanpa } \\
\text { perlakuan. } \\
\text { Intervensi dilakukan sebanyak } 3 \\
\text { kali/minggu dengan setiap sesi } 60 \\
\text { menit selama } 4 \text { bulan (48 pertemuan). }\end{array}$ & $\begin{array}{l}\text { Terdapat hasil signifikan dengan } \\
\text { nilai mean: } \\
\text { 1) Pilates Exercise } \\
\text { - Barthel Index } 100 \\
\text { - IADL scale } 15,8 \\
\text { 2) Control Group } \\
\text { - Barthel Index } 100 \\
\text { - IADL scale } 15,2 \\
\text { Pilates Exercise Group memiliki } \\
\text { nilai pre dan post (p<0,05) } \\
\text { dibandingkan Control Group. }\end{array}$ \\
\hline
\end{tabular}




\section{Pembahasan}

Semua literatur mengevaluasi peningkatan kemandirian Activity of Daily Living (ADL) setelah dilakukan Pilates Exercise dengan durasi intervensi yang berbeda di antaranya 6 sampai 20 minggu. Namun, terdapat hasil bahwa studi dengan periode waktu yang singkat juga efisien dalam meningkatkan kemandirian. Penelitian Duarte et al., (2017) terdiri dari dua periode Mat Pilates dengan kelas dua kali seminggu, masingmasing dengan 5 minggu kelas dan interval 5 minggu tanpa aktivitas apapun. Kemandirian meningkat setelah periode pertama dan menurun ketika intervensi dihentikan. Ketika periode kedua Pilates Exercise dilanjutkan, kemandirian meningkat kembali. Hal tersebut membuktikan bahwa Pilates Exercise sangat penting dilakukan demi mewujudkan lansia yang lebih mandiri.

Penelitian tersebut didukung oleh Bertoli et al., (2017) yang menunjukkan bahwa hanya dalam 6 minggu pemberian Pilates Exercise cukup signifikan dalam meningkatkan semua variabel penilaian kemandirian Activity of Daily Living (ADL) menggunakan Senior Fitness Test (SFT) Battery. Selain itu, penelitian terpanjang dilakukan oleh Carrasco et al., (2018) yang mengevaluasi Pilates Exercise, Muscular Exercise, dan Control Group selama 20 minggu yang menunjukan hasil Pilates Exercise lebih signifikan dibandingkan dengan Muscular
Exercise Group dan Control Group. Namun, terdapat penelitian Vasconcelos et al., (2016) yang menggabungkan Pilates Exercise dengan Hydrogymnastics kemudian membandingkannya dengan Functional Gymnastics dan Resistance Training. Meskipun ketiga grup memberikan dampak positif terhadap komposisi tubuh, namun Pilates Exercise Group dengan Hydrogymnastics memiliki hasil yang lebih ekspresif dibandingkan dengan grup lainnya dalam menurunkan indeks massa tubuh yang merupakan salah satu faktor pendukung kemandirian Activity of Daily Living (ADL). Oleh karena itu, Pilates Exercise terbukti efektif meningkatkan fungsi eksekutif yang merupakan strategi dalam menjaga kapasitas fungsional sehingga dalam jangka panjang dapat meningkatkan kualitas hidup lansia (Oliveira et al., 2016).

Pilates Exercise dilakukan secara rutin dengan variasi alat yang berbeda untuk mendapatkan manfaat yang maksimal. Pilates Exercise terdiri dari dua jenis metode, yaitu Mat Exercise dan Apparatus Exercise (Mueller et al., 2020). Mat Exercise adalah latihan dasar menggunakan matras sebagai media untuk meningkatkan stabilisasi, kekuatan otot core, fleksibilitas, dan mengontrol napas lansia (Vasconcelos et al., 2016). Jenis metode ini bisa dilakukan dengan bantuan beberapa alat, seperti 
swiss ball, overball, dan bands and tubing. Pada metode ini, dilakukan pemanasan selama 5 hingga 10 menit kemudian dilanjutkan dengan stretching dan isometrik (Gabizon et al., 2016). Mat Exercise dapat melatih otot agar bekerja secara sinergis, serta dapat menimbulkan perasaan senang dan rileksasi. Metode latihan ini aman digunakan oleh lansia karena tidak menimbulkan kontraksi dan gerakan yang berisiko menyebabkan trauma pada lansia (Araújo-Gomes et al., 2019).

Selain itu, Apparatus Exercise adalah metode Pilates Exercise yang memanfaatkan peralatan yang lebih besar, seperti papan bergerak dilengkapi dengan pegas, tali gantung elastis, serta kursi portable yang membuat tubuh lansia dapat meregang, memutar, dan melengkung. Jenis metode Apparatus Exercise terdiri dari alat, seperti Reformer, Cadillac, dan Wunda Chair. Alat ini menghasilkan pergerakan yang sangat bervariasi, mulai dari berdiri, duduk, dan berbaring (Carrasco et al., 2018). Metode ini secara langsung dapat membantu dalam mobilisasi sendi dan jaringan lunak, fasilitasi proprioseptif, stretching, dan strengthening secara manual sehingga dapat meningkatkan penyelarasan postur dan koordinasi tubuh melalui pergerakan melawan pegas secara konstan (Curi et al., 2017). Apparatus Exercise merupakan latihan yang aman bagi lansia karena resistensi dan modifikasi latihan dapat diatur sesuai kemampuan lansia sehingga tidak memerlukan gerakan yang berisiko, seperti melompat, berguling, dan terlalu banyak melawan gravitasi (Bertoli et al., 2017).

Berdasarkan literatur yang telah dianalisis, Pilates Exercise terbukti berpengaruh terhadap Activity of Daily Living (ADL) lansia sehat, karena secara anatomi program Pilates Exercise seperti latihan stabilisasi, strengthening, dan stretching yang dinilai potensinya untuk meningkatkan aspek postural aligment tubuh (Duarte et al., 2017). Selain itu, program Pilates Exercise yaitu Pelvic Floor Muscle Taining (PFMT) dapat memengaruhi peningkatan kekuatan otot panggul pada wanita terhadap kelompok lansia yang tidak banyak bergerak. Latihan single leg circle, single leg stretch-twist spine, dan swan and spine stretch forward pada Pilates Exercise dapat menggerakkan tungkai bawah dengan mempertahankan posisi netral panggul yang stabil dengan menargetkan otot oblique, multifidus, erector spinae. Secara psikologis, Pilates Exercise bermanfaat bagi lansia karena dapat meminimalkan tingkat keparahan gejala penuaan dan demensia, peningkatan harga diri, penurunan rasa malu sosial, serta meningkatkan rasa percaya diri lansia dalam menjalani aktivitas sehari-hari (Araújo-Gomes et al., 2019). 
${ }^{1}$ Dhea Anandha Aulia, ${ }^{2}$ Indah Ameilia Radnaningayu, ${ }^{3}$ Eka Anintyas Pandini, ${ }^{4}$ Yasyinta Ayu Qoriah, ${ }^{5}$ Fadiya Yasmin D.A Aulia, I.A Radnaningayu, E.A Pandini, Y.A Qoriah \& F.Y Robbani Fisiomu.2021 Vol 2(3): 220-233

\section{Kesimpulan dan Saran}

Berdasarkan hasil pembahasan di atas maka dapat disimpulkan bahwa Pilates Exercise efektif dalam meningkatkan kemandirian Activity of Daily Living (ADL) pada lansia sehat. Bentuk evaluasi yang diwujudkan berdasarkan assesment tools di antaranya Barthel Index, Katz Scale, IADL Scale, Senior Fitness Test (SFT) Battery, dan GDLAM Index. Oleh karena itu, disarankan agar fisioterapis menggunakan Pilates Exercise untuk menjaga kemandirian lansia sehat. Bagi masyarakat dapat dijadikan edukasi sebagai upaya preventif pada lansia sehat dalam melaksanakan Activity of Daily Living (ADL).

\section{Ucapan Terima Kasih}

Pada penyusunan studi literatur yang sederhana ini, penulis mendapat bantuan dari berbagai pihak. Oleh karena itu, penulis mengucapkan terima kasih kepada Bapak Ganesa Puput Dinda Kurniawan, SST., M.Fis. yang telah membimbing kami dalam menyusun paper ini. Penulis juga mengucapkan kepada semua pihak yang tidak dapat kami sebutkan satu per satu.

\section{Daftar Pustaka}

Andrew, G., \& Wong, R. A. (2012). Geriatric Physical Therapy. In Elsevier.

Araújo-Gomes, R. C., Valente-Santos, M., Vale,
R. G. D. S., Drigo, A. J., \& BorbaPinheiro, C. J. (2019). Effects of resistance training, tai chi chuan and mat pilates on multiple health variables in postmenopausal women. Journal of Human Sport and Exercise, 14(1), 122-139. https://doi.org/10.14198/jhse.2019.141.10

Badan Kependudukan dan Keluarga Berencana Nasional (BKKBN). (2019). Info Demografi. LD-FEB Universitas Indonesia No. 2 Tahun 2019, 2. www.bkkbn.go.id

Bertoli, J., Biduski, G. M., \& de la Rocha Freitas, C. (2017a). Six weeks of Mat Pilates training are enough to improve functional capacity in elderly women. Journal of Bodywork and Movement Therapies, 21(4), 1003-1008. https://doi.org/10.1016/j.jbmt.2016.12.001

Carrasco, M. P., Rubio-Arias, J. A., BallestaGarcía, I., \& Ramos-Campo, D. J. (2018). Pilates vs. muscular training in older women. Effects in functional factors and the cognitive interaction: A randomized controlled trial. Physiology and Behavior, 201 , 157-164. https://doi.org/10.1016/j.physbeh.2018.12. $\underline{008}$

Curi, V. S., Haas, A. N., Alves-Vilaça, J., \& Fernandes, H. M. (2017). Effects of 16weeks of Pilates on functional autonomy 
D.A Aulia, I.A Radnaningayu, E.A Pandini, Y.A Qoriah \& F.Y Robbani Fisiomu.2021 Vol 2(3): 220-233 DOI: $10.23917 /$ fisiomu.v2i3.15006

and life satisfaction among elderly women. Journal of Bodywork and Movement Therapies, 22(2), 424-429. https://doi.org/10.1016/j.jbmt.2017.06.014 Duarte, D. da S., Sousa, C. A. de, \& Nunes, C. R. de O. (2017). Effect of Pilates method and conversation circles on the health of older adults TT - Efeito do método Pilates e das rodas de conversa na saúde de idosos. Fisioterapia Em Movimento, 30(1), 39-48. https://doi.org/10.1590/19805918.030.001.ao04

Fourie, M., Gildenhuys, G. M., Shaw, I., Shaw, B. S., Toriola, A. L., \& Goon, D. T. (2013). Effects of a Mat Pilates Programme on Body Composition in Elderly Women. The West Indian Medical Journal, 62(6), 524528. https://doi.org/10.7727/wimj.2012.107

Gabizon, H., Press, Y., Volkov, I., \& Melzer, I. (2016). The effects of Pilates training on balance control and self-reported health status in community-dwelling older adults: A randomized controlled trial. Journal of Aging and Physical Activity, 24(3), 376383 https://doi.org/10.1123/japa.2014-0298 Mueller, D., Redkva, P. E., Fernando de Borba, E., Barbosa, S. C., Krause, M. P., \& Gregorio da Silva, S. (2021). Effect of mat vs. apparatus pilates training on the functional capacity of elderly women.
Journal of Bodywork and Movement Therapies, 25 (December), 80-86. https://doi.org/10.1016/j.jbmt.2020.11.012

Nations, U. (2019). World Population Ageing 2019. In World Population Ageing 2019. Department of Economic and Social Affairs http://link.springer.com/chapter/10.1007/97 8-94-007-5204-7_6

Oliveira, L. C. De, Pires-Oliveira, D. A. D. A., Prado, R. C. A. Do, Oliveira, D. P. D. De, Antônio, T. Del, Oliveira, R. F. De, \& Oliveira, R. G. De. (2016). Effects of Pilates on postural balance and functional autonomy of elderly: a randomized controlled trial. Manual Therapy, Posturology \& Rehabilitation Journal, 1-6. https://doi.org/10.17784/mtprehabjournal.2 $\underline{016.14 .327}$

RI, P. P. (2004). Peraturan Pemerintah RI Nomor 43 Tahun 2004 Tentang Pelaksanaan Upaya Peningkatan Kesejahteraan Sosial Lanjut Usia. Pelaksanaan Upaya Peningkatan Kesejahteraan Sosial Lanjut Usia. https://peraturan.bpk.go.id/

Riskesdas. (2018). Laporan Nasional Riset Kesehatan Dasar. Kementerian Kesehatan RI, Badan Penelitian Dan Pengembangan Kesehatan, Riskesdas, 1-582.

Uraningsari, F., \& Djalali. (2016). Penerimaan 


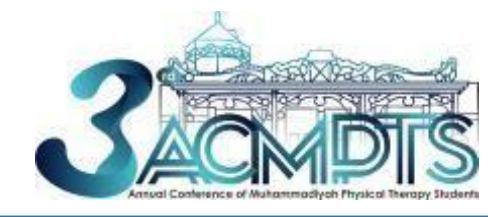

D.A Aulia, I.A Radnaningayu, E.A Pandini, Y.A Qoriah \& F.Y Robbani Fisiomu.2021 Vol 2(3): 220-233 DOI: $10.23917 /$ fisiomu.v2i3.15006

Diri, Dukungan Sosial dan Kebahagiaan Pada Lanjut Usia. Jurnal Psikologi Indonesia, $5(01)$.

https://doi.org/10.30996/persona.v5i01.738 Vasconcelos, A. P. S. L., Cardozo, D. C., Lucchetti, A. L. G., \& Lucchetti, G. (2016). Comparison of the effect of different modalities of physical exercise on functionality and anthropometric measurements in community-dwelling older women. Journal of Bodywork and Movement Therapies, 20(4), 851-856. https://doi.org/10.1016/j.jbmt.2016.02.010

Naufal, A. F., Khasanah, D. A. \& Noviyana,U., 2020. Hubungan Derajat Quadriceps Angle Dengan Patella Femoral Pain. FISIO MU: Physiotherapy Evidences. 1(1), pp. 29-34. http://doi.org/10.23917/j.fisiomu.v1i1.9 
D.A Aulia, I.A Radnaningayu, E.A Pandini, Y.A Qoriah \& F.Y Robbani Fisiomu.2021 Vol 2(3): 220-233

DOI: $10.23917 /$ fisiomu.v2i3.15006

\section{LAMPIRAN}

\section{Cek Plagiarisme}

$\Xi$ quetext

Fenomena peningkatan populasi lansia menjadi isu penting bagi dunia. Saat ini semakin

banyak masalah penurunan kemamouan fisik lansia yang dapat mempengaruhi

pencapaian activity of daily living (ADL) pada lansia. Sehingga diberikan intervensi pilates

exercise yang dapat menjaga fungsional fisik demi mewujudkan lansia yang lebih aktif

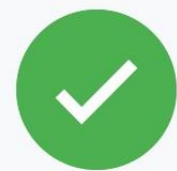

No plagiarism found

dan produktif. Jenis penelitian ini systematic literature review dengan variabel bebas

pilates exercise dan variabel terikat activity of daily living (ADL). Sampel penelitian pada

lansia sehat dan tidak memiliki masalah kesehatan kronis. Pengumoulan data dilakukan

secara online melalui 3 search engine dengan kata kunci yang dikembangkan

berdasarkan PICOS. Waktu pengumpulan data tanggal 30 Mei 2021. Didapatkan 9

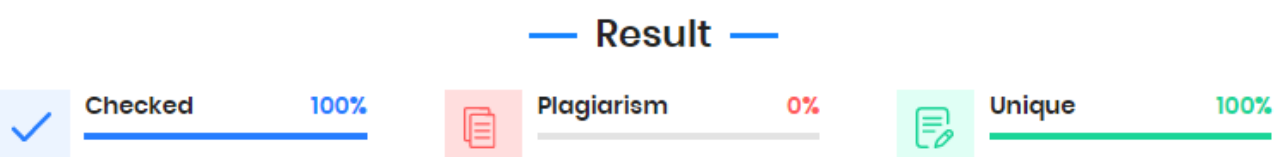

$\equiv$ Sentence Wise Results

$\prod_{\rightarrow+\infty}$ Matched Sources

Q Document View

\begin{tabular}{|c|c|}
\hline Unique & Fenomena peningkatan populasi lansia menjadi isu penting bagi dunia. \\
\hline Unique & Saat ini semakin banyak masalah penurunan kemampuan fisik lansia yang dapat mempengaruhi pencapaia... \\
\hline Unique & Sehingga diberikan intervensi pilates exercise yang dapat menjaga fungsional fisik demi mewujudkan lansia... \\
\hline Unique & Jenis penelitian ini systematic literature review dengan variabel bebas pilates exercise dan variabel terikat a... \\
\hline Unique & Sampel penelitian pada lansia sehat dan tidak memiliki masalah kesehatan kronis. \\
\hline Unique & Pengumpulan data dilakukan secara online melalui 3 search engine dengan kata kunci yang dikembangkan... \\
\hline Unique & Didapatkan 9 literatur dengan desain clinical trial dan randomized controlled trial, menghasilkan adanya pen... \\
\hline
\end{tabular}

